\title{
Cr(VI) biosorption: Effect of temperature, particle size and bed height
}

\author{
Biosorción de Cr(VI): Efecto de la temperatura, tamaño de partícula y altura del lecho
}

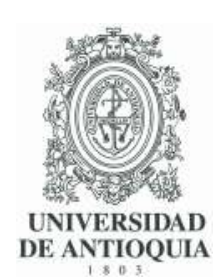

\author{
Candelaria Nahir Tejada-Tovar (1) ${ }^{1 *}$, Angel Villabona-Ortíz (ib ${ }^{1}$, Rodrigo Ortega-Toro (10) ${ }^{2}$ \\ ${ }^{1}$ Grupo de Investigación en Diseño de procesos y Aprovechamiento de Biomasas (IDAB), Programa de Ingeniería Química, Facultad de \\ Ingeniería, Universidad de Cartagena. Avenida del Consulado, calle 30 \# 39 B - 192. C. P. 130015. Cartagena, Colombia. \\ ${ }^{2}$ Food Packaging and Shelf Life (FP\&SL), Programa de Ingeniería de Alimentos, Facultad de Ingeniería, Universidad de Cartagena. \\ Avenida del Consulado, calle 30 \# 39 B - 192.C. P. 130015. Cartagena, Colombia.
}

\section{CITE THIS ARTICLE AS:}

C. N. Tejada, A. Villabona, and R. Ortega. "Cr(VI) biosorption: Effect of temperature, particle size and bed height", Revista Facultad de Ingeniería Universidad de Antioquia, no. 96, pp. 78-86, Jul-Sep 2020. [Online]. Available: https: //www.doi.org/10.17533/ udea.redin. 20191149

\section{ARTICLE INFO:}

Received: June 17, 2019 Accepted: November 11, 2019 Available online: November 11, 2019

\section{KEYWORDS:}

Metal; mathematical model; thermodynamic; wastewater treatment

Metal; modelo matemático; termodinámica; tratamiento de aguas residuales
ABSTRACT: The present work aimed to evaluate the effect of temperature, particle size and bed height of the chromium (VI) adsorption process using plantain peels in a continuous system. The experiment was carried out on a packed bed column, adjusting the feed temperature of the solution with a REX-C100 controller coupled to a type $\mathrm{K}$ thermocouple. The initial concentration of $\mathrm{Cr}(\mathrm{VI})$ was set at $100 \mathrm{ppm}$, the pH at 2 and the feed rate of $0.75 \mathrm{~mL} / \mathrm{s}$. The analyses were performed by UV-Vis spectroscopy using the colourimetric method of 1.5-diphenylcarbazide. The material was characterized by infrared spectrometry by Fourier Transforms (FTIR), from this analysis, it was determined that the $\mathrm{OH}$ and $\mathrm{NH}_{2}$ functional groups are the main responsible for the formation of complexes with the cations in solution. Also, it was established that only the particle size is statistically significant. According to the response surface analysis, the optimum conditions of the process were $353.15 \mathrm{~K}$, a particle size of $0.819 \mathrm{~mm}$ and a bed height of $67,768 \mathrm{~mm}$. From the thermodynamic study of the process, it is established that it is endothermic and the chemical adsorption prevails in it. The results obtained in the process modelling suggest that Dose-Response can be used reliably to scale the process.

RESUMEN: El objetivo de la presente investigación fue evaluar el efecto de la temperatura, tamaño de partícula y altura de lecho del proceso de adsorción de Cromo (VI) usando cáscaras de plátano en sistema continuo. La experimentación se realizó en una columna de lecho empacado, ajustando la temperatura de alimentación de la solución con un controlador REX-C100 acoplado a un termopar tipo K. La concentración inicial de $\mathrm{Cr}$ (VI) fue fijada en $100 \mathrm{ppm}$, el pH en 2 y el caudal de alimentación de 0,75 $\mathrm{mL} / \mathrm{s}$. Los análisis fueron realizados por espectroscopia UV-Vis usando el método colorimétrico de la 1,5-Difenilcarbazida. La caracterización del material se realizó mediante espectrometría infrarroja por Transformadas de Fourier (FTIR), a partir de este análisis se determinó que los grupos funcionales $\mathrm{OH}$ y $\mathrm{NH}_{2}$ son los principales responsables de la formación de complejos con los cationes en solución. Además, se estableció que solo el tamaño de partícula es estadísticamente significativo. De acuerdo con el análisis de superficie de respuesta, las condiciones óptimas del proceso fueron $353.15 \mathrm{~K}$, tamaño de partícula de $0,819 \mathrm{~mm}$ y altura de lecho de $67.768 \mathrm{~mm}$. Del estudio termodinámico del proceso, se establece que es endotérmico y prevalece una adsorción química en el mismo. Los resultados obtenidos en el modelado del proceso sugieren que el modelo de Dosis-Respuesta se puede usar de manera confiable para escalar el proceso.

\section{Introduction}

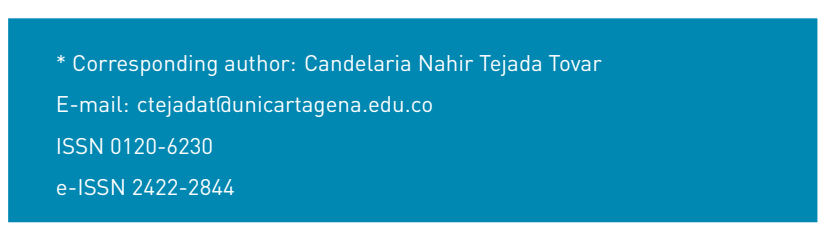

Heavy metals are continuously released from different sources such as industrial, agroindustrial and domestic waste into the environment, generating problems for 
human and aquatic organisms. The contamination of water resources, due to the indiscriminate use of heavy metals such as cadmium, zinc, cobalt, nickel, chromium, among others, has been a worldwide concern in recent years, as a result of accelerated industrialization and urbanization [1, 2]. Chromium is one of the most toxic heavy metals. Its wide distribution in the earth's crust and its multiple applications in industries that include mining, electrodeposition, leather, and pigment production means that it can be found in the wastewater [3, 4]. If ingested beyond the maximum concentration $(0.1 \mathrm{ppm})$, it can cause health disorders, such as vomiting and haemorrhage $[5,6]$.

Due to the adverse effects of $\mathrm{Cr}$ (VI) on human health and aquatic ecosystems, several chemical and physical technologies have been developed to remove metal ions from wastewater, including ionic exchange, solvent extraction, chemical precipitation, membrane filtration, and electrochemical treatment [7]. However, these traditional techniques have their inherent limitations, such as low removal efficiency at low concentrations, sensitive operating conditions and high operating cost. On the other hand, the Colombian regulation about the punctual discharge to bodies of marine water establishes that the $\mathrm{Cr}(\mathrm{VI})$ discharge concentrations must be between 0.2-0.5 ppm, under Resolution 0883 of May 2018 [8]. However, concentrations of this metal could reach up to $450 \mathrm{ppm}$, for industrial effluents $[9,10]$. Among the various physicochemical processes, adsorption is one of the most effective and easy to implement methods $[11,12]$.

Currently, the use of agricultural waste as an adsorbent is being widely considered due to its accessibility, low cost and its physicochemical characteristics, also, these agricultural waste materials could take an important role in the national economy when being used correctly [13]. Plantain is one of the main fruits that are consumed worldwide in large quantities. Despite its different uses, a large amount of plantain peels is wasted every year, and its elimination states a serious problem. The application of plantain peels as an adsorbent is advantageous for the elimination of the various water pollutants, since being a material of lignocellulosic nature; it is related to functional groups such as hydroxyls, carboxyls and amines, which have an excellent capacity for joining metal ions using a pair of electrons to form complexes in solution [14]. Thus, for the development of the present work, the efficiency of the biomass in the continuous system was evaluated by varying the temperature, bed height and particle size. This study was done to determine the optimum condition in which a higher percentage of chromium concentration is removed. Moreover, the effect on the thermodynamics of the process was analysed.

\section{Materials and methods}

\subsection{Experimental design}

A central composite design was carried out to study the adsorption tests in a continuous system: $2^{2}+$ rotatable star with 3 levels of variation (temperature, particle size and bed height). The STATGRAPHICS Centurion XVII software was used, as shown in Table 1.

\subsection{Preparation of the adsorbent}

The plantain peels were supplied by local businesses in the city of Cartagena (Bolívar) as a residue of their food production processes. The preparation of the material consisted of a wash with water to remove the dirt. Then, a manual size reduction was carried out to facilitate its handling in the later stages, a wash with distilled water was carried out to eliminate tannins, resins or other compounds that can affect the biosorption process [15]. Finally, it was dried in the oven for $8 \mathrm{~h}$ and $279.15 \mathrm{~K}$. This material was milled and sieved in different sizes, and the size between 0.15 and $1 \mathrm{~mm}$ was chosen. The chemistry of the surface of the material was evaluated through FTIR spectroscopy before and after the adsorption process to determine the functional groups involved.

\subsection{Adsorption tests in continuous system and effect study}

The removal capacity of the biomaterial was evaluated by performing tests on the packed bed equipment with continuous flow in an acrylic column as is shown in Figure 1.

The description of the elements of the continuous adsorption equipment is shown in Table 2.

The solution containing the ions under study flowed to the column by gravity, with a flow rate of $0.75 \mathrm{~mL} / \mathrm{s}$, being adjusted using a globe valve. The column was packed with the biomass by varying the temperature, particle size and bed height, in order to determine the optimal condition and the influence of each parameter. The variation and control of the temperature were carried out using a REX C-100 temperature controller. The $\mathrm{Cr}$ (VI) solution at $100 \mathrm{ppm}$ was prepared from $283 \mathrm{mg}$ of potassium dichromate $\left(\mathrm{K}_{2} \mathrm{Cr}_{2} \mathrm{O}_{7}\right)$ per litre of water.

Samples to measure the final concentration of the ions in the solution were taken at the lower outlet of the column. The concentration data were determined with UV-VIS spectrophotometry using the colourimetric method of 1.6 Diphenylcarbazide at $540 \mathrm{~nm}$ [16]. The removal efficiency (\%) for each condition was determined 
Table 1 Experimental design

\begin{tabular}{lllllll}
\hline \multirow{2}{*}{ Independent variables } & \multirow{2}{*}{ Unit } & \multicolumn{2}{l}{ Rank and level } \\
\cline { 3 - 7 } & & $\mathbf{- \alpha}$ & $\mathbf{- 1}$ & $\mathbf{0}$ & $\mathbf{+ 1}$ & $\mathbf{+} \boldsymbol{\alpha}$ \\
\hline Temperature & $\mathrm{K}$ & 302.923 & 313.15 & 328.15 & 343.15 & 353.377 \\
Particle size & $\mathrm{mm}$ & 0.212 & 0.355 & 0.6775 & 1.00 & 1.2199 \\
Bed height & $\mathrm{mm}$ & 6.137 & 30.0 & 65 & 100 & 123.9 \\
\hline
\end{tabular}

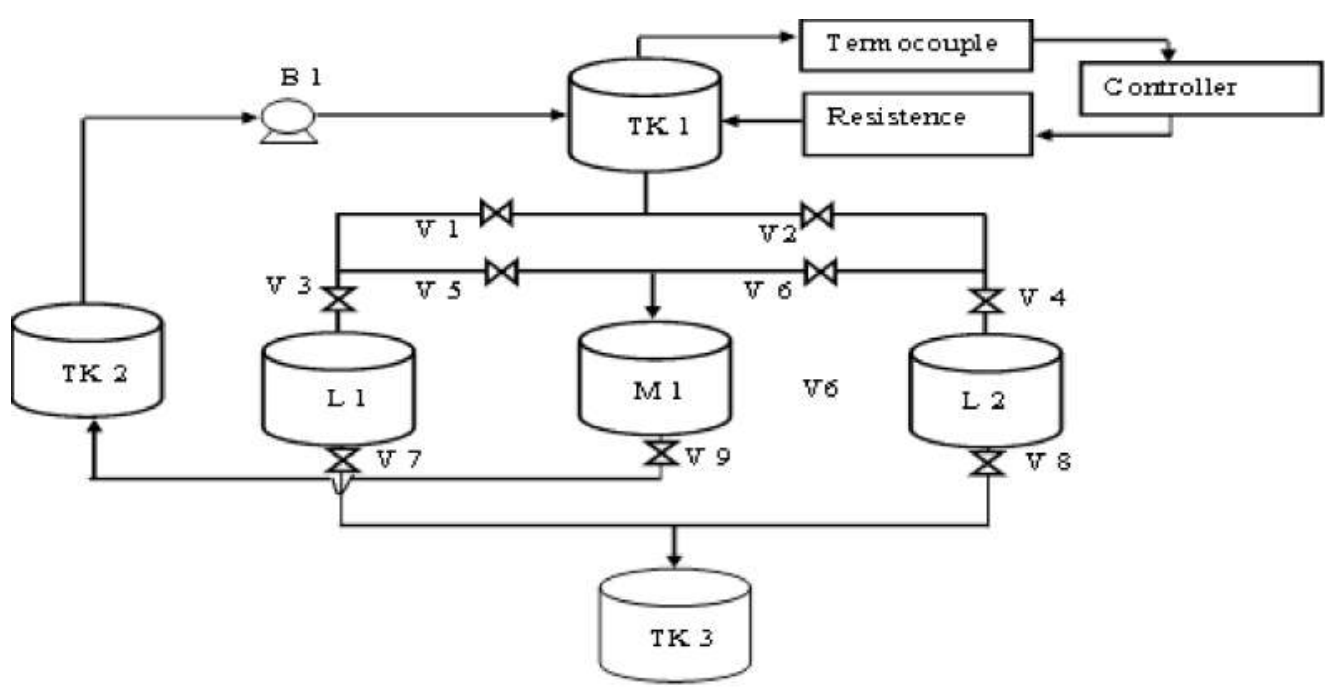

Figure 1 Flowchart of continuous adsorption equipment

Table 2 Elements of the continuous adsorption equipment

\begin{tabular}{|c|c|c|c|}
\hline Nomenclature & Equipment & Function & Description \\
\hline Resistance & Electric resistance & Heating the solution & Resistance of $220 \mathrm{~V}$ \\
\hline Thermocouple & Thermocouple & Measuring temperature & Thermocouple type $\mathrm{K}$ \\
\hline Controller & Controller & Keeping a set temperature & Controller REX-C100 \\
\hline TK 1 & Constant height tank & Maintaining the solution height & \\
\hline TK 2 & Feed tank & Feeding the solution & Acrylic tank of $5 \mathrm{~mm}$ thickness and \\
\hline TK 3 & Output tank & Arranging the solution at the exit & \\
\hline Pipeline & Pipeline & Solution transport & $\begin{array}{l}\text { Tube of chlorinated vinyl polychloride } \\
3 / 4 \text { inch }\end{array}$ \\
\hline V $1-\vee 2$ & Valve & Calibrating outflow & Gate valve of $3 / 4$ inch \\
\hline$\vee 3-V 4$ & Valve & Allowing flow of solution to the bed & Ball valve of Polyvinylchloride $3 / 4$ inch \\
\hline$\vee 5-\vee 6$ & Valve & Allowing solution flow out to bed & Gate valve $3 / 4$ inch \\
\hline L1 - L 2 & Bed tube & Storing biomass bed & $\begin{array}{l}\text { Acrylic tube of } 44.4 \mathrm{~mm} \text { diameter and } \\
280 \mathrm{~mm} \text { height }\end{array}$ \\
\hline B 1 & Bomb & Pumping solution from TK 2 to TK 3 & \\
\hline
\end{tabular}

based on Equation 1 [17]:

$$
(\%)=\left[\frac{C_{0}-C_{T}}{C_{0}} \times 100\right]
$$

Where $C_{T}$ is the remaining concentration of the ion (mg/L) and $C_{0}$ the initial concentration in the solution, indicates the value of the actual removal percentage by the continuous adsorption system. The statistical analysis of the experiments was carried out using an ANOVA analysis of variance.

\subsection{Break curve}

The rupture curve is performed to establish the shelf life and saturation point of the bed as the solution circulates over time. Thus, the $\mathrm{Cr}$ (VI) adsorption advance curve using plantain peel as a filling packed of the continuous bed was used at the best experimental conditions found after the execution of the tests proposed in the experimental design of Table 1, during 480 min, for an initial concentration of 100 ppm. Then, the adjustment of the data to the adsorption models in the continuous system was performed using the 
Table 3 Adsorption models in continuous system

\begin{tabular}{|c|c|c|c|}
\hline Model & Equation & Parameters & Meaning \\
\hline Adams & $C_{0} \operatorname{EXP}\left(K_{A B} C_{0} t\right)$ & $K_{A B}\left(\mathrm{~L} / \mathrm{mg}^{*} \mathrm{~min}\right)$ & Adams-Bohart Kinetic Constant \\
\hline Bohart & & $N_{0}(\mathrm{mg} / \mathrm{L})$ & Volumetric adsorption capacity \\
\hline \multirow{3}{*}{ Thomas } & \multirow{3}{*}{$\frac{C_{0}}{C}=\frac{1}{1+E X P\left[\frac{K_{T} H}{Q}\left(q_{0} X-C_{0} V\right)\right]}$} & $K_{T H}$ & Thomas constant \\
\hline & & & \\
\hline & & $q_{0}(\mathrm{mg} / \mathrm{g})$ & $\begin{array}{l}\text { Maximum concentration of solute } \\
\text { on the surface of the adsorbent }\end{array}$ \\
\hline \multirow{2}{*}{$\begin{array}{l}\text { Yoon- } \\
\text { Nelson }\end{array}$} & \multirow{2}{*}{$\frac{C}{C_{o}}=\frac{1}{1+e^{k} Y N(\tau-t)}$} & $K_{Y N}\left(\min ^{-1}\right)$ & $\begin{array}{l}\text { Yoon-Nelson's proportionality } \\
\text { constant }\end{array}$ \\
\hline & & $\tau(\min )$ & $\begin{array}{l}\text { Time required to retain } 50 \% \\
\text { of the adsorbate }\end{array}$ \\
\hline \multirow{2}{*}{$\begin{array}{l}\text { Dose- } \\
\text { Response }\end{array}$} & \multirow{2}{*}{$\frac{C}{C_{0}}=1-\frac{1}{1+\left(\frac{C_{0} Q t}{q_{0} X}\right)^{a}}$} & $q_{0}(\mathrm{mg} / \mathrm{g})$ & $\begin{array}{l}\text { Maximum concentration of solute } \\
\text { in the solid phase }\end{array}$ \\
\hline & & $a$ & D-R constant \\
\hline
\end{tabular}

OriginPro 8 software, and they are shown in Table $3[18,19]$.

Subsequently, the Equation 2 was used to calculate the capacity of the column $(\mathrm{mg} / \mathrm{g})$ :

$$
q_{\text {etotal }}=\frac{Q}{1000 \mathrm{~m}} \int_{0}^{T}\left(C_{o}-C_{t}\right) d t
$$

Where, $Q$ is the flow rate $(\mathrm{mL} / \mathrm{min}) ; m$, the amount of adsorbent (g); $C_{0}$ and $C_{t}$, the initial and final concentration of the metal in solution (mg/L) [20].

\subsection{Thermodynamics of the process}

In order to calculate the thermodynamic parameters, the graphical method based on the Van't Hoff equation was used, therefore, the change in standard Gibbs free energy $(\triangle G)$ was estimated by using Equations 3 and 4, enthalpy $(\triangle H)$ and standard entropy $(\triangle S)$ using Equation 5 in its graphic form.

$$
\begin{gathered}
\triangle G=\triangle H-T \triangle S \\
\triangle G=-R T * \ln K_{c} \\
\ln K_{c}=\frac{-\triangle H}{R * T}+\frac{\triangle S}{R}
\end{gathered}
$$

Where $K_{c}=C_{a c} / C_{s e} ; C_{a c}$ is the concentration of the adsorbate at equilibrium contained in the surface of the adsorbent; $C_{s e}$ is the solution concentration at equilibrium and $R$ is the universal gas constant $(8.314 \mathrm{~J} / \mathrm{mol} \cdot \mathrm{K})$ [21]. The $\left(\triangle H^{\circ}\right)$ and $\left(\triangle S^{\circ}\right)$ are determined from the slope and the intercept with the axis and the Arrhenius graph of $\ln K c$ vs $T^{-1}$, respectively, by applying the Van't Hoff graphical method [22].

\section{Results and discussion}

\subsection{Characterization}

From the FTIR analysis shown in Figure 2, functional groups contained in the biomaterial and those that can participate in the process were determined.

From the process before and after the adsorption, the change in the intensity of peaks in the wavelengths of $3,300 \mathrm{~cm}^{-1}$ corresponding to the $-\mathrm{OH}$ functional group is observed, at $2,914 \mathrm{~cm}^{-1}$ it is related to the vibrations of the $\mathrm{CH}$ bonds, at $1748 \mathrm{~cm}^{-1}$ with the group $-\mathrm{NH}_{2}$ and at $900 \mathrm{~cm}^{-1}$ were attributed to the vibration of the $\mathrm{CM}$ (carbon-metal) bonds. Thus, the $\mathrm{OH}$ and $\mathrm{NH}_{2}$ groups are related to the bands responsible for the formation of complexes with the cations in solution, and the $\mathrm{CH}$ group does not participate directly in the formation of the complex, however, its decrease can be attributed to an equalization of the intensity due to the formation of complexes [23].

\subsection{Adsorption tests and effects study}

In Table 4, the adsorption efficiency of the different conditions studied is shown, finding that the proposed biomaterial present favourable adsorption results. This fact may be associated with the lignocellulosic characteristics of the material related to the presence of hydroxyl, carboxyl and amino functional groups that have been related to the high metal removal [24].

Table 5, ANOVA divides the variability of adsorption efficiency into separate pieces for each of the effects. Then, it tests the statistical significance of each effect by comparing its mean square against an estimate of the experimental error. In this case, the particle size has a $\mathrm{P}$-value of less than 0.05 indicating that it is significantly 


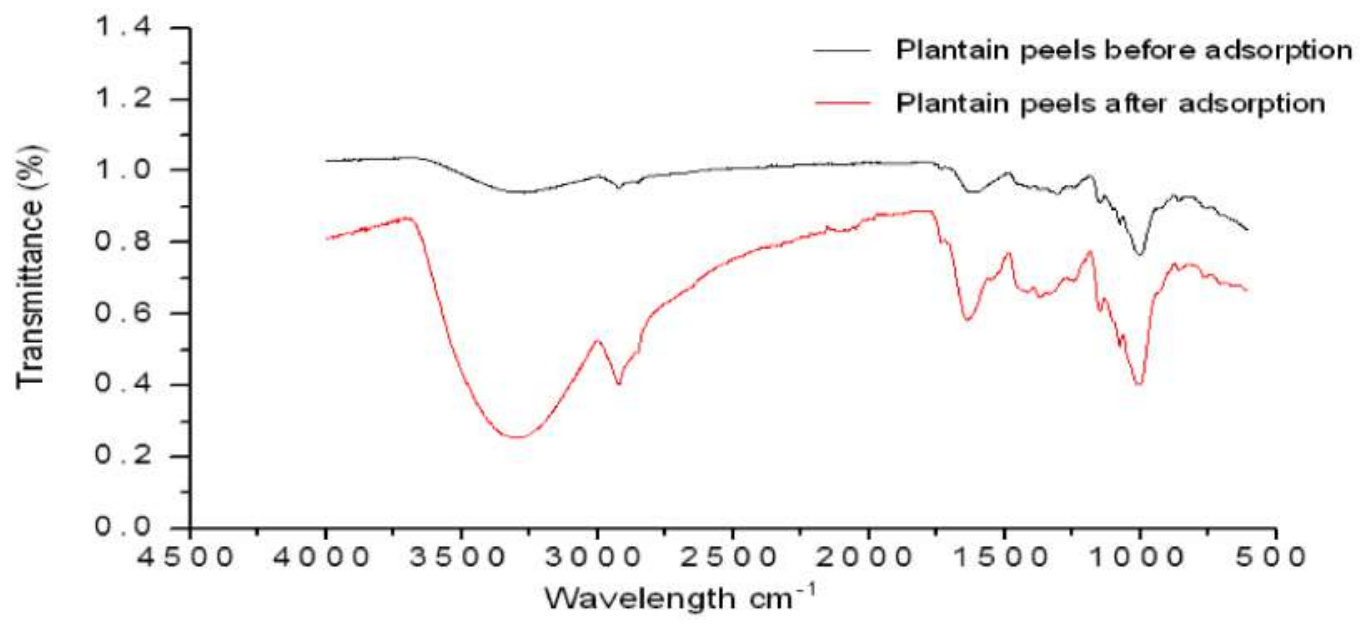

Figure 2 Plantain peels' FTIR before and after chromium adsorption

Table 4 Adsorption efficiency $\mathrm{Cr}$ (VI) in continuous system using plantain peels

\begin{tabular}{llll}
\hline Temperature $(\mathbf{K})$ & Particle size $\mathbf{( m m )}$ & Bed height $\mathbf{( m m )}$ & Adsorption efficiency $\mathbf{\%})$ \\
\hline 313.15 & 0.355 & 100 & 97.076 \\
343.15 & 0.355 & 30 & 97.330 \\
328.15 & 0.15 & 65 & 88.559 \\
328.15 & 0.678 & 65 & 99.618 \\
328.15 & 1.0 & 65 & 99.860 \\
353.377 & 0.678 & 65 & 100 \\
343.15 & 1.0 & 30 & 100 \\
343.15 & 0.355 & 100 & 100 \\
328.15 & 0.678 & 65 & 99.618 \\
343.15 & 1.0 & 100 & 98.855 \\
313.15 & 1.0 & 100 & 99.122 \\
313.15 & 0.355 & 30 & 96.695 \\
313.15 & 1.0 & 30 & 97.457 \\
328.15 & 0.678 & 123.86 & 97.839 \\
328.15 & 0.678 & 6.137 & 97.457 \\
302.923 & 0.678 & 65 & 99.237 \\
\hline
\end{tabular}

Table 5 ANOVA for $\mathrm{Cr}(\mathrm{VI})$ adsorption in continuous system using plantain peles

\begin{tabular}{llllll}
\hline Source & Sum of squares & Gl & Mean Square & F-test & P-value \\
\hline A:Temperature & 3.709 & 1 & 3.709 & 0.61 & 0.463 \\
B:Particle Size & 39.887 & 1 & 39.887 & 6.61 & 0.043 \\
C:Bed height & 1.299 & 1 & 1.299 & 0.22 & 0.659 \\
AA & 0.859 & 1 & 0.859 & 0.14 & 0.719 \\
AB & 0.206 & 1 & 0.206 & 0.03 & 0.859 \\
AC & 0.034 & 1 & 0.034 & 0.01 & 0.943 \\
BB & 23.944 & 1 & 23.944 & 3.97 & 0.093 \\
BC & 0.799 & 1 & 0.799 & 0.13 & 0.728 \\
CC & 1.424 & 1 & 1.424 & 0.24 & 0.644 \\
Total Error & 36.202 & 6 & 6.034 & & \\
Total (corr.) & 116.927 & 15 & & & \\
\hline
\end{tabular}

different from zero with a confidence level of $95.0 \%$, being the only significant effect on the adsorption of $\mathrm{Cr}$ (VI).
The R-Square statistic indicates that the model, thus adjusted, explains $69.039 \%$ of the variability in the adsorption efficiency. The adjusted R-squared statistic, 
which is more suitable for comparing models with a different number of independent variables, is $22.597 \%$. The standard error of the estimate shows that the standard deviation of the residuals is 2.456 . The absolute mean error (AME) of 1.138 is the average value of the residuals. The Durbin-Watson (DW) statistic tests the residuals to determine if there is any significant correlation based on the order in which the data is presented in the file. Since the $P$-value is higher than $5.0 \%$, there is no indication of serial autocorrelation in the residuals with a level of significance of $5.0 \%$.

In Figure 3, the effect of the parameters studied on adsorption efficiency is plotted, thus it is established that as the particle size, which is the only significant one, increases, so does the removal efficiency, which may be related to the decrease of the stagnation of the solution, which facilitates and improves the transit of fluid through the bed.

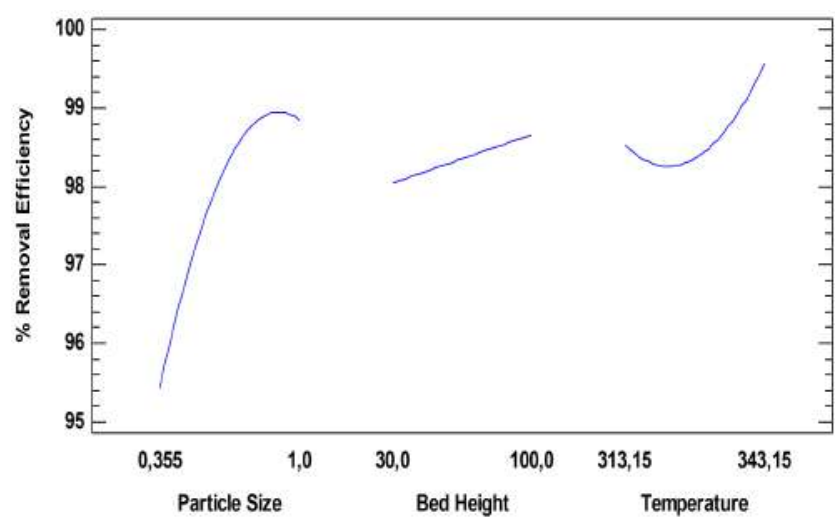

Figure 3 Main effects on the removal efficiency

However, at particle sizes of $1 \mathrm{~mm}$, a decrease occurs as a result of a slower pore diffusion rate because the diffusion trajectory along the pores is high as well as the resistance to diffusion $[25,26]$. In the case of temperature, the increase in removal efficiency due to the increase of this parameter could be due to the binding between the adsorbate and adsorbent by the formation of new active sites. These sites could form new bonds between the ions and the active functional groups on the adsorbent, overcoming the barrier of activation energy and improving the rate of intraparticular diffusion [27]. For the bed height, the behaviour could be explained by the increase in the penetration time of the solution, which represents a longer residential solution time in the bed column. Consequently, the metal has more time to diffuse into the solid phase. This fact proves that at the highest level of the bed, the diffusion towards the solid phase dominates over the axial dispersion although it is observed that at given bed height, a maximum of ion retention is reached by the surface of the material, which affects the decrease in removal at such a bed height [28].
Table 6 shows the combination of the factor levels, which maximizes the removal efficiency over the region indicated in Figure 4.

Table 6 Optimum values for $\mathrm{Cr}$ (VI) adsorption in continuous system using plantain peels

\begin{tabular}{llll}
\hline Factor & Low & High & Optimum \\
\hline Temperature (K) & 302.923 & 353.376 & 353.377 \\
Particle size $(\mathrm{mm})$ & 0.135 & 1.219 & 0.819 \\
Bed heigh $(\mathrm{mm})$ & 6.137 & 123.863 & 67.768 \\
\hline
\end{tabular}

In practice, the smaller pore sizes produce stagnation of the solution in the upper part of the bed so that the outflow of the liquid in the lower part decreases. Due to this, a mean bed height with an average particle size ensures proper execution of the experiments. Regarding the temperature, the highest one was taken as optimum, which suggests a possible endothermic process, favoured with an increase in temperature. However, it is noted that the other temperature values evaluated also show good percentages of removal, between 88 and $99 \%$, considering that in practice, additional energy consumption, referred to the heating of the solution, would not be necessary.
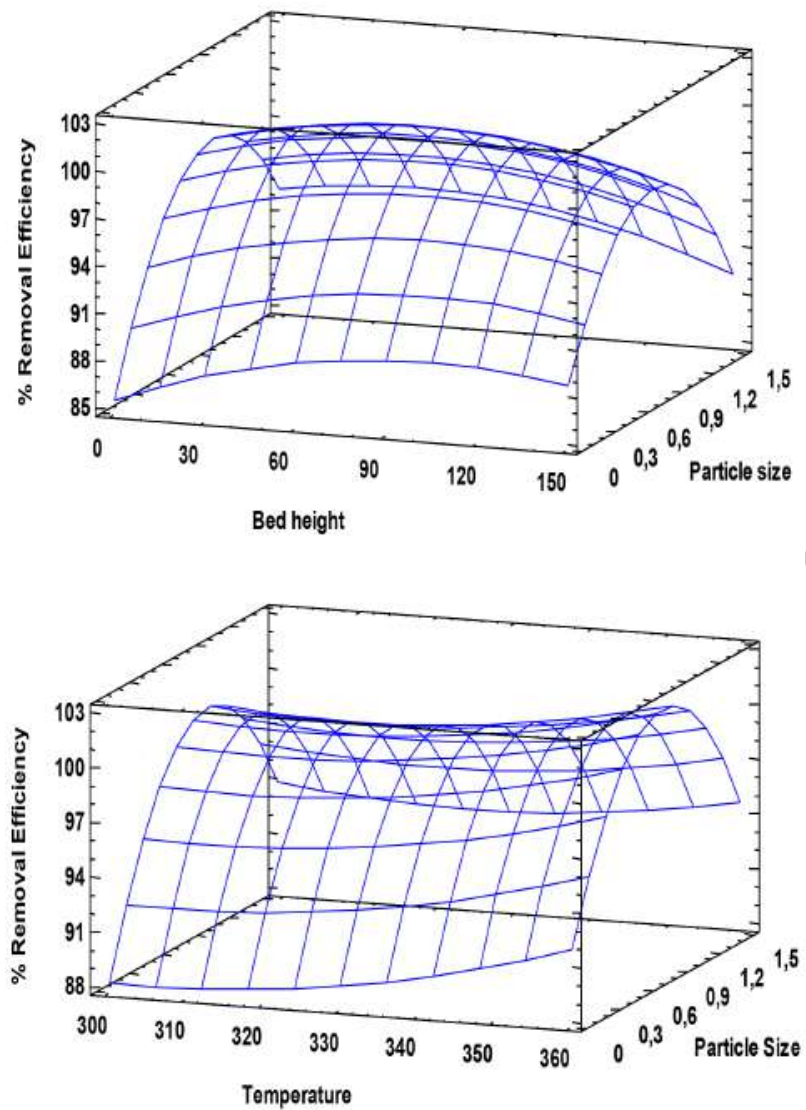

Figure 4 Estimated response surface for percentage Removal Efficiency 


\subsection{Rupture curve modeling}

Factor values that resulted in a higher removal were selected and were implemented for the configuration of the packed column and operation of adsorption tests. To establish the useful life and breakage of the bed through an advance curve during a period of $480 \mathrm{~min}$, where this better condition was corroborated due to the high removal made by the adsorption column for an initial concentration of $100 \mathrm{ppm} \mathrm{Cr}$ (VI), pH 2, $303.15 \mathrm{~K}$, and flow rate of 0.75 $\mathrm{mL} / \mathrm{s}$.

It is observed that the breaking time of the column is $300 \mathrm{~min}$, where the output concentration was $7.3 \mathrm{ppm}$, and therefore, the removal percentage was $92.7 \%$. Then, using Equation 2 and calculating the area under the curve, it was determined that the total amount of metal removed after $8 \mathrm{~h}$ of experimentation is $989.191 \mathrm{mg}$ corresponding to $86,856 \%$ of total removal. Likewise, as the solution continued to flow, the output concentration began to increase. However, during the $8 \mathrm{~h}$ of the process, the saturation of the material was not reached, indicating the high adsorption potential of the plantain peel [20].

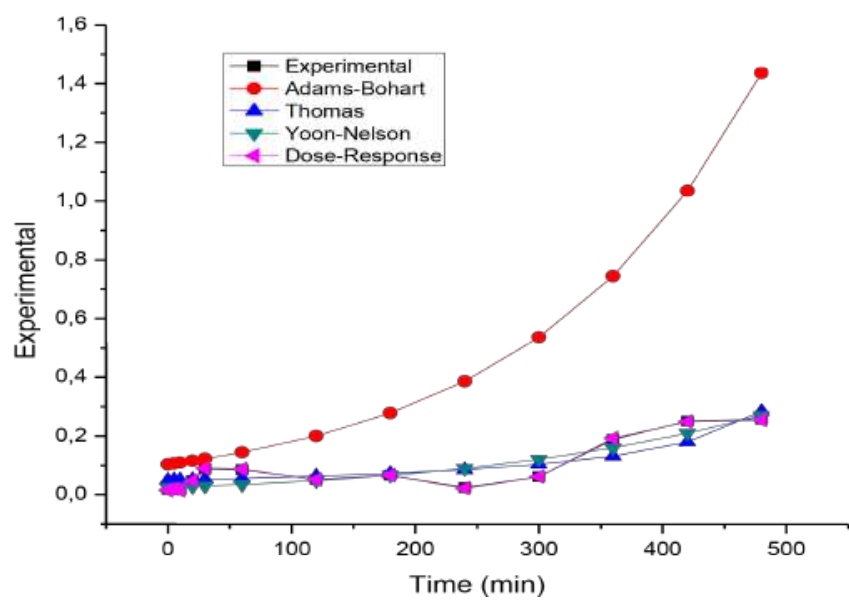

Figure 5 Fitting of $\mathrm{Cr}$ adsorption breakage curve models (VI)

Table 7 shows the adjustment of the Response Dose, Yoon-Nelson, and Thomas models to the experimental data and the calculated parameters.

The best-fitted model in the column adsorption system was chosen according to the determined correlation coefficient $\left(R^{2}\right)$ [29]. From the adjustment of Figure 5 and the values of the sum of errors (SS) and $R^{2}$, it is established that the process behaviour is described by the Dose-Response model, which adjusts to the entire advance curve. Also, it is observed that the $q_{0}$ calculated by the model $(21.723 \mathrm{mg} / \mathrm{g})$ is very close to the experimental value obtained $(25 \mathrm{mg} / \mathrm{g}$ ). The adjustment of the entire rupture curve to this model was also reported in similar works with olive seeds [30], Spirulina platensis
Table 7 Adjustment parameters for continuous system adsorption models

\begin{tabular}{lll}
\hline Model & Parameter & Value \\
\hline \multirow{4}{*}{ Adams-Bohart } & $K_{A B}(\mathrm{~L} / \mathrm{min} * \mathrm{mg})$ & $5.476 \times 10^{-5}$ \\
& $N_{0}(\mathrm{mg} / \mathrm{L})$ & 7056.355 \\
& $\mathrm{SS}$ & 0.277 \\
& $R^{2}$ & 0.905 \\
\hline \multirow{4}{*}{ Thomas } & $K_{T H}(\mathrm{~mL} / \mathrm{min} * \mathrm{mg})$ & 0.341 \\
& $q_{0}(\mathrm{mg} / \mathrm{g})$ & 2.872 \\
& $\mathrm{SS}$ & 0.002 \\
& $R^{2}$ & 0.884 \\
\hline \multirow{3}{*}{ Yoon-Nelson } & $K_{Y N}(1 / \mathrm{min})$ & 0.006 \\
& $\tau(\mathrm{min})$ & 660.030 \\
& $\mathrm{SS}$ & 0.002 \\
& $\mathrm{R} 2$ & 0.900 \\
\hline \multirow{3}{*}{ Dose-Response } & $q_{0}(\mathrm{mg} / \mathrm{g})$ & 1.155 \\
& $\mathrm{SS}$ & 21.723 \\
& $R^{2}$ & $5.887 \times 10^{-6}$ \\
& & 0.999 \\
\hline
\end{tabular}

cyanobacteria [31], orthophosphoric acid-activated lignin [32], Chinese pumpkin [33], cocoa shell [34, 35], allspice [36], among other biomaterials used for the removal of $\mathrm{Cr}(\mathrm{VI})$, reaching adjustments higher than $92 \%$. In this way, the adjustment to the Dose-Response model allows, through the value of its parameters, to obtain an expression that reproduces the behavior of the columns in other experimental conditions, without the need for additional experiments, maintaining the same operating conditions of the system fixed bed as well as its scaling [35].

\subsection{Thermodynamic parameters}

The results of the thermodynamic parameters calculated for the adsorption of $\mathrm{Cr}(\mathrm{VI})$ plantain peel are shown in Table 8.

Table 8 Values of the thermodynamic parameters for $\mathrm{Cr}$ (VI) adsorption

\begin{tabular}{llll}
\hline $\mathbf{T}(\mathrm{K})$ & $\triangle \mathbf{G}^{\circ}(\mathrm{J} / \mathrm{mol})$ & $\triangle \mathbf{H}^{\circ}(\mathrm{J} / \mathrm{mol})$ & $\triangle \mathbf{S}^{\circ}(\mathrm{J} / \mathrm{mol} * \mathrm{~K})$ \\
\hline 303.15 & 15623 & 195362 & 593 \\
328.15 & 801 & - & - \\
353.15 & -14022 & - & - \\
\hline
\end{tabular}

The positive values in the change of enthalpy $\left(\triangle \mathrm{H}^{\circ}\right)$ indicating that the adsorption process is endothermic, as the diffusion is an endothermic process, the temperature of the solution could have increased the adsorption of ions from of the aqueous solution [37]; this is evidenced in the adsorption results presented in Tables 6 and 8 . In addition, the value of the enthalpy change $\left(\triangle H^{\circ}\right)$ is $195362 \mathrm{~J} / \mathrm{mol}$, which is in the range between 20000 and 
$400000 \mathrm{~J} / \mathrm{mol}$, thus, it is suggested that the process is dominated by a chemical adsorption mechanism, where the functional groups on the surface of the adsorbent behave as active sites that can interact through chemical bonds [38, 39]. On the other hand, the positive value in the change of entropy $\left(\triangle S^{\circ}\right)$ warns the possible reversibility of the process, indicating an increase in the randomness in the liquid-solid interface during the adsorption process, which suggested that the ions of $\mathrm{Cr}$ (VI) could replace some water molecules previously adsorbed on the surface of the adsorbent $[40,41]$.

On the other hand, the change in the Gibbs free energy $\left(\triangle G^{\circ}\right)$ decreased proportionally with the increase in temperature, indicating that the process of adsorption of $\mathrm{Cr}$ (VI) in aqueous solution becomes more favorable at higher a temperature, which provides an increase in the removal capacity of the studied ions. However the system presents two stages in the adsorption process, the positive values of the change of the Gibbs free energy $\left(\triangle G^{\circ}\right)$ indicate a non-spontaneous system for adsorption, since it is unable to evolve by itself, meanwhile the negative value suggested that the process of adsorption of $\mathrm{Cr}$ (VI) with the plantain peel is thermodynamically feasible at a temperature of $353.15 \mathrm{~K}$ [42].

\section{Conclusions}

The removal of $\mathrm{Cr}$ (VI) in a continuous system using plantain peel was efficient to the studied conditions, determining that, from all the evaluated parameters, only the particle size is significant in the adsorption efficiency. A temperature of $353.15 \mathrm{~K}$, the particle size of $0.82 \mathrm{~mm}$ and a bed height of $67.768 \mathrm{~mm}$ was found as an optimum condition. According to the thermodynamics of the process, chemical adsorption is suggested, establishing that the predominant mechanism may be the formation of complexes between the metal and the functional groups of the adsorbent, it is also determined that the process is endothermic, and it is favoured at high temperatures. Although the process has an endothermic nature, at temperatures evaluated in the design of experiments, good removal percentages are obtained. The results obtained in the present investigation suggest that the Dose-Response model can be used reliably to scale the process, considering the variables involved.

\section{Declaration of competing interest}

None declared under financial, profesional and personal competing interests.

\section{Acknowledgements}

Thanks to the University of Cartagena for their support on laboratory equipments, time assigned for research activities as well as to their teaching and researching staff.

\section{References}

[1] L. B. Tahar, M. H. Oueslati, and M. J. Abdelmageed, "Synthesis of magnetite derivatives nanoparticles and their application for the removal of chromium (VI) from aqueous solutions," Journal of Colloid and Interface Science, vol. 512, February 15 2018. [Online]. Available: https://doi.org/10.1016/j.jcis.2017.10.044

[2] M. Torab-Mostaedi, M. Asadollahzadeh, A. Hemmati, and A. Khosravi, "Equilibrium, kinetic, and thermodynamic studies for biosorption of cadmium and nickel on grapefruit peel," Journal of the Taiwan Institute of Chemical Engineers, vol. 44, no. 2, March 2013. [Online]. Available: https://doi.org/10.1016/j.jtice.2012.11.001

[3] A. R. Albis, J. D. Ortiz, and J. E. Martínez, "Remoción de cromo hexavalente de soluciones acuosas usando cáscara de yuca (Manihot esculenta): Experimentos en columna," INGE CUC, vol. 13, no. 1, January 2017. [Online]. Available: https://doi.org/10.17981/ingecuc. 13.1.2017.04

[4] A. Albis, L. V. Cajar, and M. I. Domínguez, "Análisis cinético de la adsorción de $\mathrm{Cr}(\mathrm{VI})$ en soluciones acuosas a concentraciones de $10-20 \mathrm{mg} / \mathrm{L}$ con el uso de cáscara de yuca amarga (Manihot esculenta)," Prospectiva, vol. 13, no. 2, July 2015. [Online]. Available: hhttps://doi.org/10.15665/rp.v13i2.488

[5] J. Zhou and et al, "Effective removal of hexavalent chromium from aqueous solutions by adsorption on mesoporous carbon microspheres," Journal of Colloid and Interface Science, vol. 462, January 15 2016. [Online]. Available: https://doi.org/10.1016/j.jcis. 2015.10.001

[6] C. Tejada, A. Villabona, and M. Jiménez, "Remoción de cromo hexavalente sobre residuos de cacao pretratados químicamente," Revista UDCA Actualidad \& Divulgación Científica, vol. 20, no. 1, January 2017. [Online]. Available: https://doi.org/10.31910/rudca. v20.n1.2017.71

[7] C. Tejada, A. Villabona, V. Caballero, J. Paternina, and C. Granados, "Optimización de parámetros para la construcción de la curva de ruptura en la adsorción de $\mathrm{Cr}$ (VI) sobre cáscara de cacao," Revista UDCA Actualidad \& Divulgación Científica, vol. 21, no. 1, January 2018. [Online]. Available: https://doi.org/10.31910/rudca.v21.n1.2018.675

[8] Ministerio de Medio Ambiente y Desarrollo Sostenible. (2018, May 18) Resolución 0883. [Online]. Available: https://bit.ly/2ND6kfp

[9] C. Tejada, A. Villabona, and L. Garcés, “Adsorción de metales pesados en aguas residuales usando materiales de origen biológico," TecnoLógicas, vol. 18, no. 34, pp. 109-123, 2015.

[10] A. Villabona, C. N. Tejada, and R. Ortega, "Modelling of the adsorption kinetics of chromium (VI) using waste biomaterials," Revista Mexicana de Ingeniería Química, vol. 19, no. 1, January 2020. [Online]. Available: https://doi.org/10.24275/rmiq/IA650

[11] Y. F. Lam, L. Y. Lee, S. J. Chua, S. S. Lim, and S. Gan, “Insights into the equilibrium, kinetic and thermodynamics of nickel removal by environmental friendly lansium domesticum peel biosorbent," Ecotoxicology and Environmental Safety, vol. 127, May 2016. [Online]. Available: https://doi.org/10.1016/j.ecoenv.2016.01.003

[12] E. Largo, M. Cortés, and H. J. Ciro, “The adsorption thermodynamics of sugarcane (Saccharum officinarum l.) powder obtained by spray drying technology," Vitae, vol. 21, no. 3, pp. 165-177, Sep. 2014.

[13] A. Ali, "Removal of Mn(II) from water using chemically modified plantain peels as efficient adsorbent," Environmental Nanotechnology, Monitoring \& Management, vol. 7, May 2017. [Online]. Available: https://doi.org/10.1016/j.enmm.2016.12.004

[14] S. Singh, N. Parveen, and H. Gupta, "Adsorptive decontamination of rhodamine-B from water using plantain peel powder: A biosorbent," 
Environmental Technology \& Innovation, vol. 12, November 2018. [Online]. Available: https://doi.org/10.1016/j.eti.2018.09.001

[15] B. C. Maniglia and D. R. Tapia, "Isolation and characterization of starch from babassu mesocarp," Food Hydrocolloids, vol. 55, April 2016. [Online]. Available: https://doi.org/10.1016/j.foodhyd.2015.11. 001

[16] K. S. Padmavathy, G. Madhu, and P. Haseen, “A study on effects of $\mathrm{pH}$, adsorbent dosage, time, initial concentration and adsorption isotherm study for the removal of hexavalent chromium (Cr (VI)) from wastewater by magnetite nanoparticles," Procedia Technology, vol. 24, 2016. [Online]. Available: https://doi.org/10.1016/j.protcy. 2016.05.127

[17] Y. Wu and et al, "Functionalized agricultural biomass as a low-cost adsorbent: utilization of rice straw incorporated with amine groups for the adsorption of $\mathrm{Cr}(\mathrm{VI})$ and $\mathrm{Ni}$ (II) from single and binary systems," Biochemical Engineering Journal, vol. 105, January 15 2016. [Online]. Available: https://doi.org/10.1016/j.bej.2015.08.017

[18] D. S. Malik, C. K. Jain, and A. K. Yadav, "Heavy metal removal by fixedDbed column-a review," ChemBioEng Reviews, vol. 5, no. 3, May 28 2018. [Online]. Available: https://doi.org/10.1002/cben. 201700018

[19] S. Srivastava, S. B. Agrawal, and M. K. Mondal, "Fixed bed column adsorption of $\mathrm{Cr}(\mathrm{VI})$ from aqueous solution using nanosorbents derived from magnetite impregnated phaseolus vulgaris husk," Environmental Progress \& Sustainable Energy, vol. 38, no. s1, May 4 2019. [Online]. Available: https://doi.org/10.1002/ep.12918

[20] A. Abdolali and et al, "Application of a breakthrough biosorbent for removing heavy metals from synthetic and real wastewaters in a lab-scale continuous fixed-bed column," Bioresource Technology, vol. 229, April 2017. [Online]. Available: https://doi.org/10.1016/j. biortech.2017.01.016

[21] F. Granados, J. Bonifacio, and J. Serrano, "Estudio cinético y termodinámico de la adsorción de $\mathrm{Cr}$ (VI) presente en solución acuosa sobre fosfato de calcio sintético," Revista de la Sociedad Química del Perú, vol. 75, no. 2, pp. 201-212, Apr. 2009.

[22] M. K. Rai and et al, "Adsorption of hexavalent chromium from aqueous solution by activated carbon prepared from almond shell: kinetics, equilibrium and thermodynamics study," Journal of Water Supply: Research and Technology-Aqua, vol. 67, no. 8, December 1 2018. [Online]. Available: https://doi.org/10.2166/aqua.2018.047

[23] N. Flores, M. J. Solache, R. M. Gomez, and B. Garcia, "Estudio de adsorción competitiva de cobre y zinc en solución acuosa utilizando Q/PVA/EGDE," Revista Mexicana de Ingeniería Química, vol. 14, no. 3 , pp. 801-811, Sep. 2015.

[24] A. Abdolali and et al, "A breakthrough biosorbent in removing heavy metals: Equilibrium, kinetic, thermodynamic and mechanism analyses in a lab-scale study," Science of The Total Environment, vol. 542, January 15 2016. [Online]. Available: https://doi.org/10.1016/j. scitotenv.2015.10.095

[25] E. Oguz and M. Ersoy, "Biosorption of cobalt(II) with sunflower biomass from aqueous solutions in a fixed bed column and neural networks modeling," Ecotoxicology and Environmental Safety, vol. 99 , January 2014. [Online]. Available: https://doi.org/10.1016/j.ecoenv. 2013.10.004

[26] J. S. Valencia and G. C. Castellar, "Predicción de las curvas de ruptura para la remoción de plomo (II) en disolución acuosa sobre carbón activado en una columna empacada," Revista Facultad de Ingeniería Universidad de Antioquia, no. 66, pp. 141-158, Mar. 2013.

[27] Z. Aksu and E. Kabasakal, "Batch adsorption of 2, 4-dichlorophenoxy-acetic acid (2, 4-D) from aqueous solution by granular activated carbon," Separation and Purification Technology, vol. 35, no. 3, March 2004. [Online]. Available: https://doi.org/10.1016/S1383-5866(03)00144-8

[28] A. Mishra, B. D. Tripathi, and A. K. Rai, "Packed-bed column biosorption of chromium(VI) and nickel(II) onto fenton modified Hydrilla verticillata dried biomass," Ecotoxicology and environmental safety, vol. 132, October 2016. [Online]. Available: https://doi.org/ 10.1016/j.ecoenv.2016.06.026
[29] N. Sivarajasekar, N. Mohanraj, R. Baskar, and S. Sivamani, "Fixed-bed adsorption of ranitidine hydrochloride onto microwave assisted-activated Aegle marmelos correa fruit shell: statistical optimization and breakthrough modelling," Arabian Journal for Science and Engineering, vol. 43, no. 5, pp. 2205-2215, May 2018.

[30] M. A. Martín, F. Hernáinz, G. Blázquez, G. Tenorio, and M. Calero, "Sorption of $\mathrm{Cr}(\mathrm{VI})$ onto olive stone in a packed bed column: Prediction of kinetic parameters and breakthrough curves," Journal of Environmental Engineering, vol. 136, no. 12, December 2010. [Online]. Available: https://doi.org/10.1061/(ASCE)EE.1943-7870. 0000281

[31] S. V. Gokhale, K. K. Jyoti, and S. S. Lele, "Modeling of chromium (VI) biosorption by immobilized Spirulina platensis in packed column," Journal of Hazardous Materials, vol. 170, no. 2-3, October 302009. [Online]. Available: https://doi.org/10.1016/j.jhazmat.2009.05.005

[32] A. B. Albadarin and et al, "Modelling and fixed bed column adsorption of $\mathrm{Cr}(\mathrm{VI})$ onto orthophosphoric acid-activated lignin," Chinese Journal of Chemical Engineering, vol. 20, no. 3, June 2012. [Online]. Available: https://doi.org/10.1016/S1004-9541(11)60208-5

[33] K. M. Sreenivas, M. B. Inarkar, S. V. Gokhale, and S. S. Lele, "Re-utilization of ash gourd (Benincasa hispida) peel waste for chromium (VI) biosorption: Equilibrium and column studies," Journal of Environmental Chemical Engineering, vol. 2, no. 1, March 2014. [Online]. Available: https://doi.org/10.1016/j.jece.2014.01.017

[34] J. A. Lara, C. Tejada, A. Villabona, A. Arrieta, and C. Granados, "Adsorción de plomo y cadmio en sistema continuo de lecho fijo sobre residuos de cacao," Revista Ion, vol. 29, no. 2, December 15 2016. [Online]. Available: https://doi.org/10.18273/revion.v29n2-2016009

[35] L. M. Vera and et al, "Modelado en columna de lecho fijo para la bioadsorción de $\mathrm{cd}^{2+} \mathrm{y} \mathrm{pb}^{2+}$ con cáscara de cacao," Revista internacional de contaminación ambiental, vol. 34, no. 4, November 2018. [Online]. Available: http://dx.doi.org/10.20937/rica.2018.34. 04.05

[36] A. Nam and et al, "Evaluation of amine-functionalized acrylic ion exchange fiber for chromium(VI) removal using flow-through experiments modeling and real wastewater," Journal of Industrial and Engineering Chemistry, vol. 66, October 25 2018. [Online]. Available: https://doi.org/10.1016/j.jiec.2018.05.029

[37] S. Rasaki, B. Zhang, S. Liu, T. Thomas, and M. Yang, "Nanourchin ZnOATiCN composites for $\mathrm{Cr}(\mathrm{VI})$ adsorption and thermochemical remediation," Journal of Environmental Chemical Engineering, vol. 6, no. 4, May 2018. [Online]. Available: https://doi.org/10.1016/j.jece. 2018.05.040

[38] W. Zhang and et al, "Hybrid functionalized chitosan- $\mathrm{Al}_{2} \mathrm{O}_{3} \mathrm{ASiO}_{2}$ composite for enhanced $\mathrm{Cr}(\mathrm{VI})$ adsorption," Chemosphere, vol. 203, July 2018. [Online]. Available: https://doi.org/10.1016/j. chemosphere.2018.03.188

[39] S. Guiza, "Biosorption of heavy metal from aqueous solution using cellulosic waste orange peel," Ecological Engineering, vol. 99, February 2017. [Online]. Available: https://doi.org/10. 1016/j.ecoleng.2016.11.043

[40] E. Malkoc and Y. Nuhoglu, "Determination of kinetic and equilibrium parameters of the batch adsorption of $\mathrm{Cr}$ (VI) onto waste acorn of Quercus ithaburensi," Chemical Engineering and Processing: Process Intensification, vol. 46, no. 10, October 2007. [Online]. Available: https://doi.org/10.1016/j.cep.2007.05.007

[41] S. Rangabhashiyam and N. Selvaraju, "Efficacy of unmodified and chemically modified Swietenia mahagoni shells for the removal of hexavalent chromium from simulated wastewater," Journal of Molecular Liquids, vol. 209, September 2015. [Online]. Available: https://doi.org/10.1016/j.molliq.2015.06.033

[42] K. C. Bedin, A. C. Martins, A. L. Cazetta, O. Pezoti, and V. C. Almeida, "KOH-activated carbon prepared from sucrose spherical carbon: Adsorption equilibrium, kinetic and thermodynamic studies for methylene blue removal," Chemical Engineering Journal, vol. 286, February 15 2016. [Online]. Available: https://doi.org/10.1016/j.cej. 2015.10.099 